\title{
IAMJ
}

INTERNATIONAL

AYURVEDIC

MEDICAL JOURNAL

\section{EFFECT OF LAGHU MALINI VASANTA RASA IN PREGNANCY - A REVIEW STUDY}

\author{
Syama Maniyankutty ${ }^{1}$, Aswathi R $\mathbf{S}^{2}$ \\ ${ }^{1}$ Assistant professor, Dept. of Rasasastra and Baishajya Kalpana, Krishna Ayurveda Medical College, \\ Vadodara, Gujarat, India \\ ${ }^{2}$ Assistant Professor, Dept. of Prasuti Tantra and Streeroga, Krishna Ayurveda Medical College, Vadodara, \\ Gujarat, India
}

Corresponding Author: syaamaabhi@gmail.com

\section{https://doi.org/10.46607/iamj1109022021}

(Published online: February 2021)

Open Access

(C) International Ayurvedic Medical Journal, India 2021

Article Received: 06/01/2021 - Peer Reviewed: 23/01/2021 - Accepted for Publication: 30/01/2021

Check for updates

\begin{abstract}
Pregnancy is the most important part of every woman's life. The union of Sukra, Sonita and Jivatma inside the Garbhasaya forms Garbha. The innermost part of Garbhasaya is filled with minute hair like capillaries which nourishes the embryo after fertilization. Pregnancy is divided into three trimesters. Throughout this period utmost care has to be taken to maintain the health of both the baby and mother. Health of baby depends upon health of mother and hence it is necessary to preserve the health of the mother. Laghumalinivasanta Rasa ${ }^{1}$ is a herbo-mineral formulation which is widely used during pregnancy. It is a well-known Vasanta Kalpa formulation. It is a suitable ayurvedic remedy to cope up with problems arising during pregnancy, as it is very helpful to stabilise the foetus, thereby reducing the tendency of abortion. It is also helpful in female health related problems like menorrhagia, leucorrhoea and reduces excessive vaginal discharge also. As per the reference of Yoga Ratnakara the main ingredients of Laghumalinivasanta rasa are ShudhaKharpara and Marichachoorna. With appropriate Anupana this medicine is effective in all types of Garbhinijwara as well as it is good for Garbhaposhana. This review article highlights the role of Laghumalinivasanta rasa in stabilising the foetus.
\end{abstract}

Keywords: Kharaliyarasayana, LaghumaliniVasanta Rasa, Pregnancy 


\section{INTRODUCTION}

God has gifted woman with the ability to keep the human species alive and hence a woman is an integral part in our society. And the woman has to go through many critical and troublesome phases during pregnancy. The problems affecting the health of the pregnant lady are multifactorial. Mother and child must be considered as one unit. During the antenatal period, the foetus obtains all the building materials from Mothers blood. Garbhasthapana drugs also favours for the growth and development of the foetus. Rasa Dhatu is responsible for the proper nourishment and providing the essential nutrients to the embryo after fertilization through Upasneha. After fertilization Garbha gets covered by Rakta. Thus, Rasa and Rakta plays important role in GarbhaSthapana. If any of these factors is not there in proper state, the Garbha will leads to miscarriage.

Vasant kalpas are KharaliyaRasayanaKalpanas, explained in Ayurveda. They promote growth of endometrium so that it gets prepared for implantation of embryo if fertilization occurs.
LaghumaliniVasanta Rasa is a well-known Kharaliya Rasayana, which is widely used for problems arising during pregnancy. LMV acts as Rasaposhaka, Yogavahi, Dipana, Pachana on Rasavaha and RaktavahaSrotas. It helps in proper nourishment of foetus during pregnancy

There is a wide scope of research in Ayurveda to find a medicine, which is safe and potent remedy to reduce the chances of abortion in first of pregnancy.

Ingredients and preparation of LaghumaliniVasanta Rasa

Shudha Kharpara and Maricha Choorna has to be taken in the ratio of 2:1 and subjected to Mardana in Navaneeta and then with Nimbu Swarasa till the Snigdhata is lost. Then it is rolled into pills of 2 Ratti (250 mg) size.

Table 1: Contents of LaghumaliniVasanta Rasa

\begin{tabular}{|l|l|l|l|}
\hline Sl No & Common name & Latin name & Part \\
\hline 1 & Rasaka & Zinc oxide & 2 part \\
\hline 2 & Maricha & Piper nigrum & 1 part \\
\hline
\end{tabular}

Table 2: Bhavana Dravya of LaghumaliniVasanta Rasa

\begin{tabular}{|l|l|l|l|}
\hline S1 No & Common name & Latin name & quantity \\
\hline 1 & NimbuSwarasa & Citrus lemon & Q S \\
\hline 2 & Navaneeta & Butter & Q S \\
\hline
\end{tabular}

Table 3: Properties of ingredients of LaghumaliniVasanta Rasa

\begin{tabular}{|l|l|l|l|l|l|l|l|}
\hline S1 No & Name & Rasa & Guna & Virya & Vipaka & Doshakarma & Actions \\
\hline 1 & Kharpara $^{2}$ & Kasaya Katu & Laghu & Sheeta & Katu & Tridoshagna & Raktapradaranaashana \\
\hline 2 & Maricha $^{3}$ & Katu & $\begin{array}{l}\text { Laghu } \\
\text { Tikshna }\end{array}$ & Ushna & Katu & $\begin{array}{l}\text { Vatakaphasa- } \\
\text { mana }\end{array}$ & Dipana \\
\hline 3 & Nimbu $^{4}$ & Amla & $\begin{array}{l}\text { Guru } \\
\text { Tikshna }\end{array}$ & Ushna & Amla & $\begin{array}{l}\text { Kaphavatasa- } \\
\text { mana }\end{array}$ & $\begin{array}{l}\text { Rochana } \\
\text { Dipana } \\
\text { Pachana }\end{array}$ \\
\hline 4 & Navaneeta $^{4}$ & Madhura & $\begin{array}{l}\text { Snigdha } \\
\text { Pichila }\end{array}$ & Sheeta & Madhura & $\begin{array}{l}\text { Vata pitta hara } \\
\text { Kaphakara }\end{array}$ & Vrishya \\
\hline
\end{tabular}


Pharmacological properties of Ingredients of LaghumaliniVasanta Rasa Actions of Kharpara Bhasma

Kharparabhasma is an excellent drug that possesses yogavahi property. It helps in treating various kinds of diseases such as all types of Prameha, Bleeding disorders, urinary diseases, respiratory infections, all kinds of fever and diarrhoea. It is also used for external application in some skin disorders like Vicharchika and Kushtas. Its judicious use will improve the physical strength and virility. It is Shukrala, Balya and Vrishya i.e. increase the capacity of ovum for fertilization. Zinc is an essential component for implantation and stimulating healthy cytokines for nidation ${ }^{6}$. It also acts on uterus and regulates hormonal imbalance which plays an important role in endometrial proliferation.

\section{Actions of Maricha}

It is a Laghu and Tikshna drug which is hot in potency and has an anti-inflammatory, anti-microbial, antispasmodic and antipyretic action. It is an effective antioxidant. Piperine the alkaloid present in it is responsible for the bio transformation of drugs and improves the bioavailability also ${ }^{6}$

\section{Actions of Nimbu}

It is a drug belonging to citrus species that possesses anti-inflammatory, hypoglycaemic, anthelmintic, anticancer and anti-infective properties. Its other actions are Rochana, Dipana, Pachana, Anulomana and Pittasaraka ${ }^{6}$

\section{Actions of Navaneeta}

It is an excellent aphrodisiac which is also used to improve strength and digestion. This drug has Sangraahi property and is very effective in haemorrhoids, facial palsy, respiratory complaints, eye diseases and all types of bleeding disorders. It also helps for the absorption of RasakaBhasma. Also, it contains lacto bacillus necessary for absorption.

\section{Dosage and Anupana of LaghumaliniVasanta Rasa} Dose - 2 Ratti (250mg) (Yoga Ratnakara)

$125 \mathrm{mg}$ (AFI)

Anupana - LaghumaliniVasanta Rasa is given along with Honey and Pippali for all types of Jwara. Along with milk it is administered in bleeding disorders, fever and eye diseases.

\section{Mechanism of action of Laghumalini Vasanta Rasa in Pregnancy}

The main content of Laghumalini Vasant Rasa is zinc, which is used in ante natal complaints. According to various studies zinc is very essential for implantation by regulating hormonal imbalance ${ }^{7}$. The available evidence suggests that zinc supplementation during pregnancy may help to reduce preterm births ${ }^{8}$. Zinc is essential in the production of Progesterone, which is the main hormone which helps in maintaining pregnancy. According Ayurveda it does "Sthitathva of Garbha" which prevent abortion especially in first trimester. Laghumalini Vasant Rasa has Sheeta Virya, which will help to increase sthanik kapha dosa, leading to endometrial nourishment, which will increase endometrial receptivity and correct implantation process.

\section{DISCUSSION}

Laghumalini Vasanta Rasa is a Katu Rasa Pradhana drug. Katu Rasa is Agni Mahabhutapradhana, hence Sthanika and SarvadehikaAgni will be increased and also Pitta Dosha will be at Saamyavastha by Dhatvagni Pachana. This will lead to balance of Kapha and VataDosha, which will help in implantation process.

Laghumalinivasant Rasa has a major role in increasing progesterone as it contains zinc in it. Thus, it helps is maintaining pregnancy especially in early trimester. As the placenta does not develop in the first trimester, the progesterone supplementation is done by Corpus luteum. Because of the Rasayana Guna of Laghumalini Vasant Rasa, it does the stimulation of corpus luteum to produce progesterone and there after it maintains the Garbha.

\section{CONCLUSION}

There is a misconception among common people that rasa preparations are harmful to the intrauterine foetus and should not be given to pregnant ladies. From the review of Laghumalini Vasant Rasa this is showing significant progestogenic activity. RasakaBhasma is the main ingredient of LaghumaliniVasanta Rasa and which is in minimum amount, which is used after the Shodhana and Marana process to make it safer to use. Bhavana is said to be given first with Navaneeta and 
then with NimbuSwarasa until GhritaVimukta stage is reached. Maricha, Nimbu Rasa and Navaneeta are also used along with RasakaBhasma which are having significant role in the process of implantation. With its proper Anupana it is giving better action.

Laghumalini Vasanta Rasa improves the quality and functioning of Rasa Dhatu and thus nourishes the remaining Dhatus which results in Garbha Poshana. This medicine is clinically proved to be effective in increasing the thickness and receptivity of endometrium by its content.

\section{REFERENCES}

1. Vaidya Laksmipati Sastri, Yogaratnakara, edited by Bhisagratna Brahmasankarsastri, Varanasi, Chaukhambha Prakashan, 2020, reprint, p 245.

2. Dr. Ravindra Angadi, A Textbook of Rasasastra, Varanasi, Chaukhamba Surbharati Prakashan,2020, ch 15, p224.

3. Prof. P. VSharma, Dravyaguna Vijnana, Varanasi, Chaukhambha Bharati Academy, reprint, 2009, ch 5, p362
4. Prof. P. V Sharma, Dravyaguna Vijnana, Varanasi, Chaukhambha Bharati Academy, reprint, 2009, ch 5, p345

5. Dr R Vidyanath, Ashtanga Hrdaya of Vagbhata, Varanasi, Chaukhamba Surbharati Prakashan, 2018, Sutrastana,5/35-36, p75

6. https://www.planetayurveda.com/library/laghu-malinivasanta-rasa/

7. www.who.int/elena/titles/zinc_pregnancy/in/clinic

8. www.mariongluckclinic.com/b/y

\section{Source of Support: Nil \\ Conflict of Interest: None Declared}

How to cite this URL: Syama Maniyankutty \& Aswathi R S: Effect Of Laghu Malini Vasanta Rasa In Pregnancy - A Review Study. International Ayurvedic Medical Journal \{online\} 2021 \{cited February, 2021\} Available from: http://www.iamj.in/posts/images/upload/396 399.pdf 